\title{
CONFIRMATION OF OCCURRENCE OF THE NARROW-CLAWED CRAYFISH ? STACUS LEPTODACTYLUS ESCHSCHOLTZ, 1823 IN THE RIVER EVROS IN GREECE
}

\author{
C. PERDIKARIS (1), E. KOUTRAKIS (2), V. SARAGLIDOU (3) and N. MARGARIS (4)
}

(1) Technological Educational Institute of Epirus, Department of Aquaculture \& Fisheries, Irinis \& Filias 1, GR-46100 Igoumenitsa. Greece

E-Mail: kperdik@otenet.gr

(2) Fisheries Research Institute of Kavala, National Agricultural Research Foundation, GR-64007, Nea Peramos, Kavala, Greece.

E-Mail: manosk@inale.gr

(3) Prefecture of Rodopi-Evros, County of Northern Evros, Fisheries Department, GR-68200, Orestiada, Greece.

(4) Department of Environmental Studies, University of the Aegean, University Hill, GR-81100, Mytilene, Greece.

E-Mail: margaris@dolnet.gr

Reçu le 8 février 2007

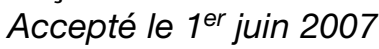

Received February 8, 2007

Accepted June 1, 2007

\begin{abstract}
The narrow-clawed crayfish Astacus leptodactylus Eschscholtz, 1823, is widely distributed in eastern European and western Asian countries. However, species presence in Greece was documented only by limited museum conserved specimens dating back to 1893. Recently (May 2005) several crayfish were captured in the Evros River (close to city of Didimotiho) and these were identified as A. leptodactylus. The present work confirms the presence of $A$. leptodactylus in the Evros River still hundred and twelve years later and introduces the possibility of $A$. leptodactylus being indigenous to Greece.
\end{abstract}

Key-words: narrow-clawed crayfish, Astacus leptodactylus, Evros River, Greece.

\section{PRÉSENCE DE L'ÉCREVISSE À PIEDS GRÊLES ? STACUS LEPTODACTYLUS ESCHSCHOLTZ, 1823 EN GRÈCE DANS LE FLEUVE EVROS}

\section{RÉSUMÉ}

L'écrevisse à pieds grêles Astacus leptodactylus Eschscholtz, 1823, est largement répandue en Europe de l'Est et dans de nombreux pays de l'Ouest de l'Asie. Cependant, la présence de cette espèce n'est documentée en Grèce que par des spécimens conservés dans des collections de musée, remontant à 1893. Récemment (mai 2005) plusieurs écrevisses ont été capturées dans le fleuve Evros (près de la ville de Didimotiho), et identifiées comme $A$. leptodactylus. Le présent travail confirme la présence de A. leptodactylus dans le fleuve Evros cent douze ans plus tard et présente la possibilité que $A$. leptodactylus est indigène en Grèce.

Mots-clés: écrevisse à pieds grêles, Astacus leptodactylus, fleuve Evros, Grèce. 


\section{INTRODUCTION}

The narrow-clawed crayfish Astacus leptodactylus Eschscholtz, 1823 is one of the five species of the Astacidae family endemic to the European continent. Its original distribution extends to the Ponto-Caspian region $(\mathrm{HOLDICH}, 2002$; MACHINO and HOLDICH, 2006; HOLDICH et al., 2006). Additionally, it has been imported to several European Union countries (SKURDAL and TAUGBØL, 2002; MACHINO and HOLDICH, 2006), mainly for farming purposes or replacing Astacus astacus (Linnaeus 1758) stocks devastated by the crayfish plague (Aphanomyces astaci Schikora, 1906).

Early reports on the species presence in Turkey were published by NINNI (1923: p. 61; under names of Astacus fluviatilis, Astacus pallipes and Astacus leptodactylus), BOTT (1950), TORTONESE (1952: p. 84; under name of Potamobius leptodactylus), HOLTHUIS (1961), KARAMAN (1962, 1963), GELDIAY and KOCATAS (1970), and PRETZMANN (1973). Then ROTH and KINZELLBACH (1986), KÖKSAL (1988) and HOLDICH et al. (2006) mapped the distribution of the species after sample collections and previous bibliographical sources. For many years, huge amounts of live $A$. leptodactylus were harvested in Turkish lakes (ROTH and KINZELBACH, 1986; KÖKSAL, 1988; HARLIOĞLU, 2004; annual harvest and export figures cited in KÖKSAL, 1988 and HOLDICH and WHISSON, 2004). The crayfish were exported live, deep frozen or cooked mainly to Swedish, French and German markets. Indigenous stocks of $A$. leptodactylus seem to be in a recovery phase after a serious decline in the populations due to the overfishing and crayfish plague. The total commercial catches of crayfish in Turkey declined from 5,000 tons in 1984 to 200 tons in 1991, while in 2000 the total annual catches increased to 1,600-1,900 tons (HOLDICH et al., 2006).

Populations of $A$. leptodactylus exist also in Bulgaria (BULGURKOV, 1961; SUBCHEV and STANIMIROVA, 1998): many sites across the Danube system and other waters of the Black Sea drainage. The species distribution has been expanded, mainly due to the water quality improvement, which is probably due to the fact that many industries have suspended their activities (ZIKOV, 1999). Nevertheless there has been no report about the existence of the species in the Bulgarian part of the River Evros (Maritsa, Meriç) yet.

The fact that $A$. leptodactylus is present in both Bulgaria and Turkey raised questions about possible current occurrence in north-eastern Greece (Evros Perfecture in Region of East Macedonia and Thrace), especially in the system of the Evros River.

Bibliographical sources on A. leptodactylus occurrence in Greek waters are extremely scarce. KARAMAN (1963) and KÖKSAL (1988) mentioned that $A$. leptodactylus was found in the Evros River system. But historical presence of $A$. leptodactylus in Greece has only been documented by few samples collected from the Evros River dating back to $19^{\text {th }}$ century and held in the Natürhistorisches Museum in Wien (NHW) (MACHINO and HOLDICH, 2006): one specimen from the Evros River close to the city of Soufli (3 October 1893, inventory No. 3090); one specimen from a tributary of the River Evros close to the Mandra village (October 1893, inventory No. 3093); and four specimens from the cities of Alexandroupolis close the delta of the River Evros and Edirne (former Adrianoupolis) on the Turkish side (inventory No. 2873) (Figure 1). KARAMAN (1963) observed these specimens and knew that $A$. leptodactylus lived in the Evros River on both sides, Greek and Turkish. He treated the species as indigenous there. But, as he did not specify the exact places on the Greek territory, later astacologists of today did not remark or even did ignore what KARAMAN (1963) meant about presence of $A$. leptodactylus on the Greek side of the Evros drainage. Thus till recent time $A$. leptodactylus had been regarded as unknown and exotic to Greece. For example, endemicity of the species to Greece was denied by KALLISTORATOS (1990) and WESTMAN et al. (1990). Nevertheless, occasionally the species was assigned as "native to Greece" as well, e.g., by SKURDAL and TAUGBØL (2002). Unfortunatly the latter authors failed to develop their argument 
about $A$. leptodactylus as native to Greece. Based on the crayfish collections in the Vienna museum (NHW), MACHINO and HOLDICH (2006) suggested that species be present in Greece and probably indigenous to.

After collected materials, the present work provides for the first time after $1893 \mathrm{a}$ proof of $A$. leptodactylus occurrence in the Greek part of the Evros River.

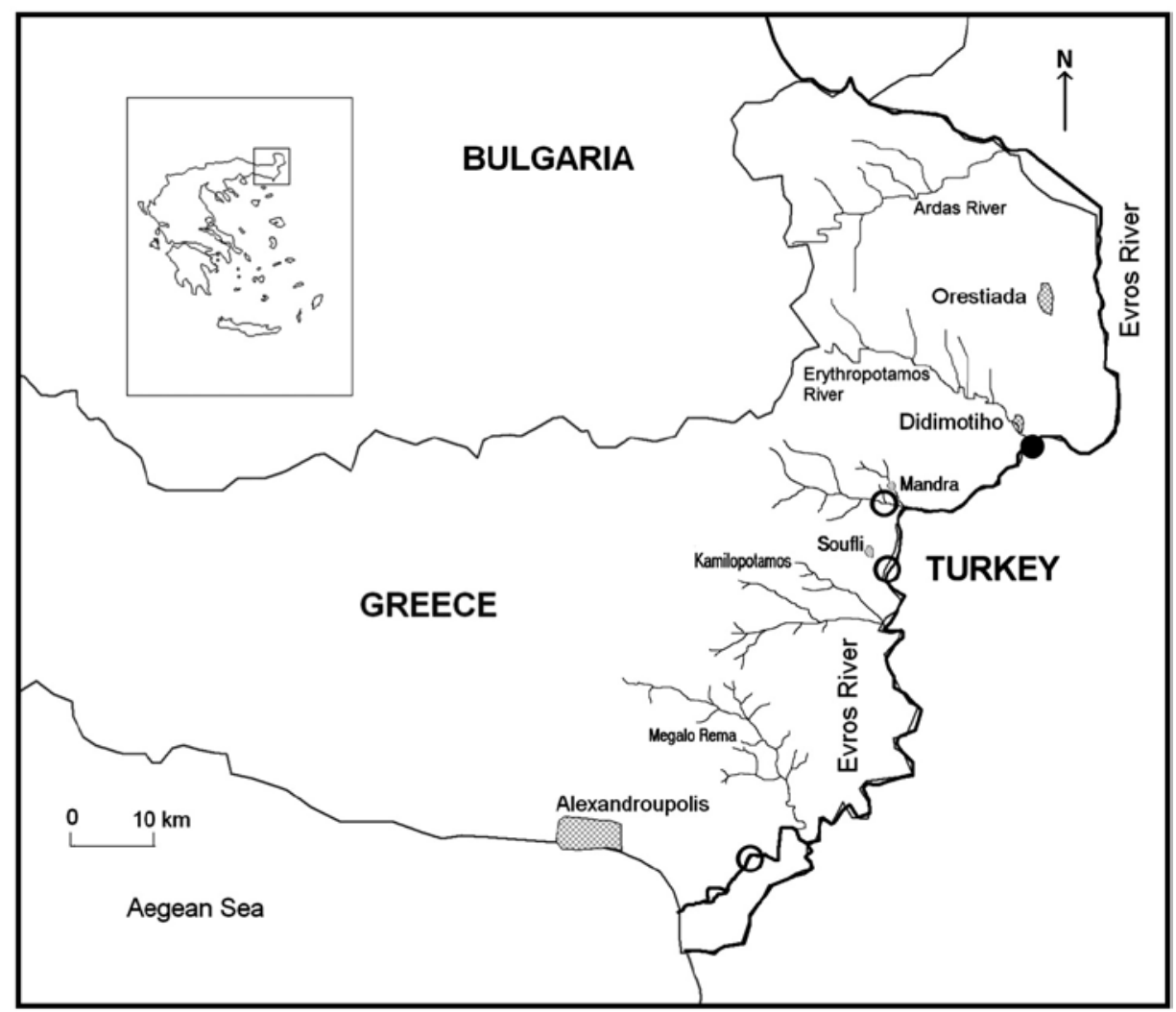

Figure 1

Map of the north-eastern part of Greece where the Evros River outflows to the Aegean Sea. Black circle indicates where the specimens of A. leptodactylus were caught in May 2005, while the open circles indicate where the museum specimens are coming from (based on the description reported by MACHINO and HOLDICH, 2006). The places located in the figure are not the exact locations, but the most probable, according to the explanations given in the text.

Figure 1

Carte de la région nord-est de la Grèce où le fleuve Evros se jette dans la mer Égée. Le cercle noir indique le lieu où des spécimens de A. leptodactylus ont été capturés en mai 2005 , alors que les cercles blancs montrent les endroits d'où proviennent les spécimens de musée (basé sur la description rapportée par MACHINO et HOLDICH, 2006). Les lieux indiqués ne représentent pas les lieux exacts, mais les plus probables, selon les explications indiquées dans le texte. 


\section{METHODS AND RESULTS}

In order to verify information about the occurrence of crayfish presence in the area of Didimotiho, May 5, 2006, two fyke-net traps $(80 \mathrm{~cm}$ diameter open end and mesh size of $6 \mathrm{~mm}$ ) were placed on two sites in the Evros River close to the city of Didimotiho (Figure 1) with the collaboration of a local fisherman. Both sites were in the main body of the river and traps were placed at a depth of $3 \mathrm{~m}$ without bait. The river substrate on both sites was sandy and with rich vegetation (aquatic macrophytes and tree roots). The following day, six crayfish were found trapped; one adult male specimen was preserved in $10 \%$ formaldehyde solution (Figure $2 \mathrm{a}, \mathrm{b}$ ) while the five others were released unharmed. All the specimens were identified as $A$. leptodactylus according to criteria referred in KARAMAN (1963), ALBRECHT (1982), SKURDAL and TAUGBØL (2002), FÜREDER and MACHINO (2002) and HOLDICH and VIGNEUX (2006). The conserved male specimen was $10.41 \mathrm{~cm}$ in total length and had characteristic narrow and thin chela. Description, sex and morphological characteristics of the specimen are shown in Table I.

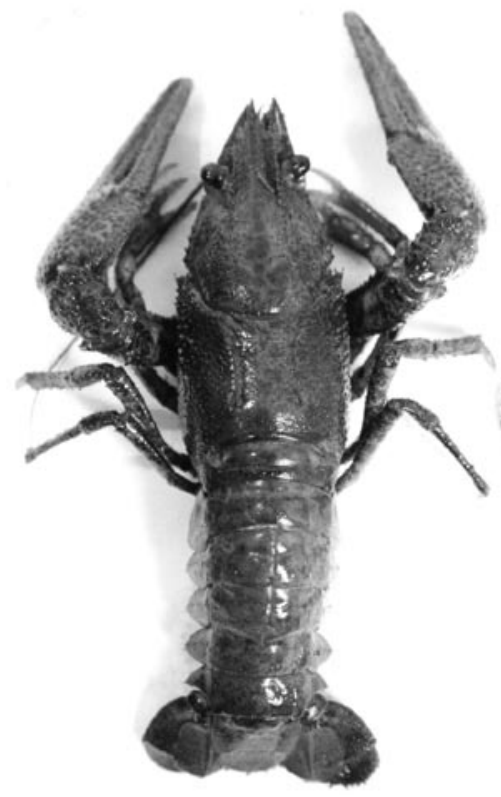

(a)

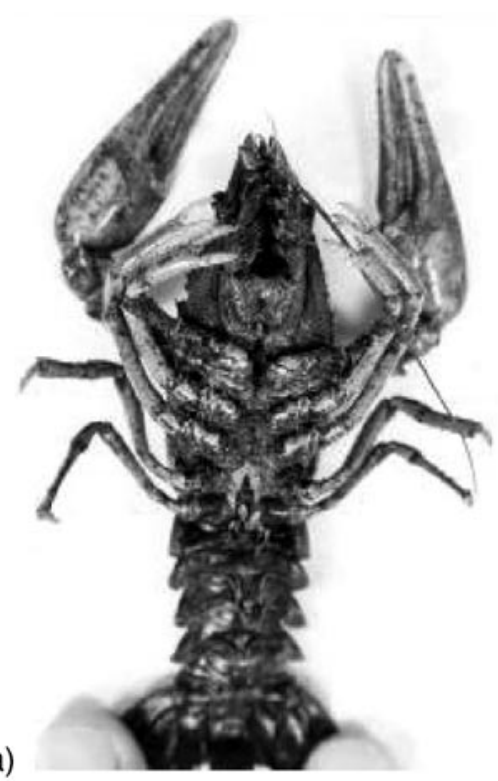

(b)

Figures 2a, b

Dorsal (a) and ventral (b) view of the male specimen of A. leptodactylus caught close to the city of Didimotiho in the River Evros.

Figure 2a, b

Vue dorsale (a) et ventrale (b) du spécimen mâle de $A$. leptodactylus capturé près de la ville de Didimotiho dans le fleuve Evros.

The Evros basin, including the Arda, Tundja and Ergene tributaries of the lower basin, is one of the major river systems located in the eastern Balkans, with a total length of $550 \mathrm{~km}$ (the second longest river on the Balkan Peninsula after the Danube) and a total catchment area of $39,000 \mathrm{~km}^{2}$. About $66 \%$ belongs to Bulgaria, $28 \%$ to Turkey and $6 \%$ to Greece. About $218 \mathrm{~km}$ of the river are located in Greece, with $203 \mathrm{~km}$ of the river forming the borderline with Turkey. The catchment area in Greece is $3,340 \mathrm{~km}^{2}$ (INWEB, 2006). 


\section{Table I}

Description, sex and morphological characteristics of $A$. leptodactylus specimen caught in the River Evros in May 2005.

\section{Tableau I}

Description, sexe et caractéristiques morphologiques du spécimen de A. leptodactylus capturé dans le fleuve Evros en mai 2005.

\begin{tabular}{ll}
\hline Sex & Male \\
\hline Cephalothorax $(\mathrm{mm})$ & 52.56 \\
Rostrum (mm) & 14.55 \\
Acumen (mm) & 6.97 (pointed with two spines on each lateral margin of \\
& the rostrum) \\
Tail without telson (mm) & 36.61 \\
Telson (mm) & 14.96 \\
Eye diameter (mm) & 3.41 \\
"'Talon" (pleopod 2) & present \\
Chela & narrow and long \\
Rostrum & elongated \\
Rostral borders & almost parallel, denticulated \\
Rostral median crista & present (14.27 mm long) with spines \\
Post-orbital ridges & two pairs (1 $1^{\text {st }}$ pair immediately behind the eyes). Each \\
& ridge with one sharp spine on the front \\
Carapace & very "rough"with four lateral spines behind of each \\
& side of the cervical groove (one pair of spines very \\
Distal border of maxilliped & prominent) \\
one prominent hard spine on the outer front part (close \\
Chela surface granulation & to carpus) \\
Colouration & big \\
& dark patches dorsally to the carapace, pereopods and \\
& claws and pale coloration ventrally to the body \\
\hline
\end{tabular}

The Evros River in Greece has poor water quality since high concentrations of nitrogen and phosphorus were measured (SKOULIKIDIS et al., 1998) and its annual dissolved inorganic nitrogen (DIN) and dissolved inorganic phosphorus (DIP) loads were found to be the highest after comparison with other Greek rivers (SYLAIOS et al, 2005) as it receives transborder pollution. The river suffers from flow disturbances (i.e. damming, dyking and fragmentation). Moreover, during the last decade severe floods have occurred along the Evros River and its tributaries and caused a lot of damage to downstream areas. For example, the alert and alarm water level for floods coming from the Evros River are set to 4.70 and $5.70 \mathrm{~m}$ respectively and the actual level reached $6.92 \mathrm{~m}$ March 14, 2006, while the normal water levels are less than $3 \mathrm{~m}$ (official unpublished data from the Department of Political Emergency Planning, Prefecture of Evros). Flooding is mainly observed during springtime with heavy rainfall and snowmelt. It is also reinforced by the overflowing of artificial lakes in the Bulgarian part of the Ardas River (tributary of the Evros River).

\section{DISCUSSION}

The identified $A$. leptodactylus specimens confirmed that the species lives in the Evros River and forms one or several populations. Moreover, the Evros represents one of the south-western limits of the species'natural distribution (HOLDICH et al., 2006) and probably a unique habitat of the species in Greece. Old data (i.e., museum collections), coupled with the present findings, suggest that the species could be indigenous in Greece. 
Among crayfish species in Europe, those of the genus Astacus are of the PontoCaspian origin, while those of the genus Austropotamobius are rather of western origin (the Balkans and western Europe) (HOBBS, 1988; HOLDICH et al., 2006). Looking at the crayfish distribution maps of Europe (HOLDICH et al., 2006), occurrence of $A$. leptodactylus in Evros River is not an isolated point within its distribution area. After the biogeographic pattern around the Ponto-Caspian basin, the distribution in the Evros clearly appears non-scattered from the main distribution. Based on biogeographical data for fish fauna (ECONOMIDIS and BANARESCU, 1991), it can be suggested that $A$. leptodactylus have reached the Evros River system along with other Ponto-Caspian taxa of brackish water or slow-running freshwater origin through the freshwater discharges of Black Sea to the Aegean Sea. The dispersal root from the north through the Stara Planina Mountain (i.e. rheophilic species of Danubian origin) should be excluded for $A$. leptodactylus, as it is not rheophilic species and is characterised by wide ecological tolerance (e.g. salinity). Recently other crayfish populations were reportedly located by local fishermen in the Pithio trench close to the city of Orestiada (Evros Prefecture, Region of East Macedonia and Thrace) and in the Ardas River (Figure 1). The vicinity of places (Didimotiho vis-à-vis the Pithio trench and the Ardas River) strongly suggests that these crayfish probably belong to the crayfish species of Didimotiho (i.e., A. leptodactylus). Nevertheless occurrence of another crayfish Austropotamobius torrentium (Schrank, 1803) in the Bulgarian parts of the Evros drainage (BULGURKOV, 1961; SUBCHEV and STANIMIROVA, 1998) and in the River Velika (tributary of the River Rezovska) in European Turkey (TRONTELJ et al., 2005) suggest that there be a possibility that $A$. torrentium is present in the Greek parts of the Evros drainage. But the main body of the Evros as well as the two crayfish places in the Ardas River and Pithio trench is characterised by muddy substrate without habitats for $A$. torrentium, thus $A$. torrentium occurrence at the two place is certainly excluded.

Apart from the Evros River system, the deliberate release or accidental escape of specimens in other freshwater or estuarine ecosystems cannot be excluded. Greece imported 4.00, 3.17 and 0.54 tons of live A. leptodactylus during 1983, 1984, and 1985, respectively (KÖKSAL, 1988). For example, several specimens may have been released into the River Pinios drainage in central Greece during the 1980s'(PALEOCOSTAS pers. comm.), although this should be verified on the field yet.

The authors are in close cooperation with the local Fisheries Department in order to help making the local fishermen sensitive for the species conservation. Crayfish are considered as by-catch by the fishermen and frequently returned back to the river. But for establishing distribution maps of $A$. leptodactylus in the Evros drainage and conserving these precious populations as well as their habitats, further research and interstate actions are urgently needed. The issuing of conservation measures for the Evros River should also be considered.

\section{ACKNOWLEDGEMENTS}

The authors would like to thank Christos Goudinadis for his valuable help in crayfish trapping and Yoichi Machino for reviewing the manuscript.

\section{REFERENCES}

ALBRECHT H., 1982. Das System der europäischen Flußkrebse (Decapoda, Astacidae): Vorschlag und Begründung. Mitteilungen aus dem Hamburgischen Zoologischen Museum und Institut, 79, 187-210.

BOTT R., 1950. Die Flußkrebse Europas (Decapoda: Astacidae). Abhandlungen der Senckenbergischen Naturforschenden Gesellschaft, 483, 1-36 + 6 pl.

BULGURKOV K., 1961. Sistematika, biologiya I zoogeografsko razprostranenie na sladtkovodnite raci ot sem. Astacidae i sem. Potamonidae v Bylgariya. Izvestija na Zoologiceskija Institute s Muzej, 10, 165-192. 
ECONOMIDIS P., BANARESCU P.M., 1991. The distribution and origins of freshwater fishes in the Balkan Peninsula, especially in Greece. Internationale Revue der Gesamten Hydrobiologie, 76 (2), 257-284.

FÜREDER L., MACHINO Y., 2002. A revised key of freshwater crayfish in Europe. Berichte des Naturwissenschaftlich-Medizinischen Vereins in Innsbruck, 89, 169$178+$ Erratum.

GELDIAY R., KOCATAS A., 1970. The preliminary report about the taxonomy and distribution of Astacus (Decapoda) in Turkey. Scientific Reports of the Faculty of Science, Ege University, 94, 1-7 + 3 plates, Izmir.

HARLIOĞLU M.M., 2004. The present situation of freshwater crayfish, Astacus leptodactylus (Eschscholtz, 1823) in Turkey. Aquaculture, 230, 181-187.

HOBBS H.H.Jr., 1988. Crayfish distribution, adaptive radiation and evolution. In: Freshwater crayfish: Biology, management and exploitation, HOLDICH D.M., LOWERY R.S. (eds.). Croom Helm, London, pp. 52-82 + 426-479.

HOLDICH D.M., 2002. Present distribution of crayfish in Europe and some adjoining countries. Bulletin Français de la Pêche et de la Pisciculture, 367, 611-650.

HOLDICH D.M., WHISSON G., 2004. The First 30 Years. A history of the International Association of Astacology. International Association of Astacology, 248 p.

HOLDICH D.M., VIGNEUX E., 2006. Key to crayfish in Europe. In: Atlas of crayfish in Europe, SOUTY-GROSSET C., HOLDICH D.M., NOËL P., REYNOLDS J.D., HAFFNER P. (eds.). Collection Patrimoines Naturels, 64, 53-55.

HOLDICH D.M., CARRAL J., FÜREDER L., GHERARDI F., MACHINO Y., PÖCKL M., SMIETANA P., TAUGBØL T., 2006. Species desription. In: Atlas of crayfish in Europe, SOUTY-GROSSET C., HOLDICH D.M., NOËL P., REYNOLDS J.D., HAFFNER P. (eds.). Collection Patrimoines Naturels, 64, 56-129 + 163-177.

HOLTHUIS L.B., 1961. Report on a collection of Crustacea Decapoda and Stomatopoda from Turkey and the Balkans. Zoologische Verhandelingen, 47, 1-67, Leiden.

INWEB, 2006. International Network of Water-Environment Centres for the Balkans (http:// www.inweb.gr/: 12 December 2006).

KALLISTORATOS G., 1990. Greece. In: Status of crayfish stocks, fisheries, diseases and culture in Europe, WESTMAN K., PURSIAINEN M., WESTMAN P. (eds.). Kalatutkimuksia-Fiskundersökningar (Helsinki), 3, 103-107.

KÖKSAL G., 1988. Astacus leptodactylus in Europe. In: Freshwater Crayfish: Biology, Management and Exploitation, HOLDICH D.M., LOWERY R.S. (eds). Croom Helm, London, pp. 365-400 + 426-479.

KARAMAN M.S., 1962. Ein Beitrag zur Systematik des Astacidae (Decapoda). Crustaceana, 3 (3), 173-191.

KARAMAN M.S., 1963. Studie der Astacidae (Crustacea, Decapoda). Hydrobiologia (The Hague), 22, 111-132.

MACHINO Y., HOLDICH D.M., 2006. Distribution of crayfish in Europe and adjoining countries: updates and comments. Freshwater Crayfish, 15, 292-323.

NINNI E., 1923. Primo contributo allo studio dei pescie della pesca nelle acque dell'Imperio Ottomano. Missione Italiana per l'Esplorazione dei Mari di Levante (materiali raccolti durante la campagna talassografica. 1921-1922 a bordo della R. Nave L.F. Marsigli), 5, 1-187 + 16 pl. + 1 map. Venezia.

PRETZMANN G., 1973. Ergebnisse einiger Sammelreisen nach Vorderasien. Annalen des Naturhistorischen Museums in Wien, 77, 331-333. 
ROTH J., KINZELBACH R., 1986. The distribution of the Pontian Crayfish, Astacus leptodactylus, in Turkey. Zoology in the Middle East, 1, 147-152.

SKOULIKIDIS N.T., BERTAHAS I., KOUSSOURIS T., 1998. The environmental state of freshwater resources in Greece (river and lakes). Environmental Geology, 36 (1/2), $1-17$.

SKURDAL J., TAUGBØL T., 2002. Crayfish of commercial importance. Astacus. In: Biology of Freshwater Crayfish, HOLDICH D.M., (ed.), pp. 467-510 + pl. 8 + pl. 19 + pl. 3441. Blackwell Science Ltd, Oxford, UK.

SUBCHEV M., STANIMIROVA L., 1998. Razprostranenie na pravite sladkovodni raci (Crustacea: Decapoda) i tehnite epibionti ot rod Branchiobdella (Annelida: Branchiobdellae), Hystricosoma chappuisi Michaelsen, 1926 (Annelida: Oligochaeta) i Nitocrella divaricata (Crustacea: Copepoda) v Bylgarija. Historia Naturalis Bulgarica, 9, 5-18.

SYLAIOS G., KAMIDIS N., MARKOU D., KOUTRAKIS E., KALLIANIOTIS A., 2005. Environmental monitoring in Nestos River Delta. Proceedings of the 12th Hellenic Congress of Ichthyologists. Drama, Greece 13-16 October 2005, p. 258-261.

TORTONESE E., 1952. Relazione preliminare di un viaggio a scopo zoologico attraverso I'Asia Minore. Bollettino dell'Istituto e Museo di Zoologia della Università di Torino, 3, 81-97 + 1 pl., Torino.

TRONTELJ P., MACHINO Y., SKET B., 2005. Phylogenetic and phylogeographic relationships in the crayfish genus Austropotamobius inferred from mitochondrial COI gene sequences. Molecular Phylogenetics and Evolution, 34, 212-226.

WESTMAN K., PURSIAINEN M., WESTMAN P., 1990. The situation of crayfish stocks, fisheries, diseases and crayfish culture in Europe - a review. In: Status of crayfish stocks, fisheries, diseases and culture in Europe, WESTMAN K., PURSIAINEN M., WESTMAN P., (eds.). Kalatutkimuksia-Fiskundersökningar (Helsinki), 3, 5-31.

ZIKOV A., 1999. Crayfish culture in Bulgaria. Crayfish News - IAA Newsletter, April 1999, 21 (2), 25-26. 